Polymer Journal, Vol. 3, No. 2, pp 234-241 (1972)

\title{
The Synthesis and Polymerization of Methylvinyloxygermanes
}

\author{
Sueo Kida, Shun-ichi Nozakura, and Shunsuke Murahashi \\ Department of Polymer Science, Faculty of Science, \\ Osaka University, Toyonaka, Osaka, Japan.
}

(Received September 21, 1971)

\begin{abstract}
Methylvinyloxygermanes, $\left(\mathrm{CH}_{3}\right)_{4-n} \mathrm{Ge}\left(\mathrm{OCH}=\mathrm{CH}_{2}\right)_{n}(n=1 \sim 3)$, were synthesized by the reaction of the corresponding methylchlorogermanes and mercuridiacetaldehyde.

As a by-product of trimethylvinyloxygermane $(n=1)$, its tautomer, trimethylgermylacetaldehyde $\left(\mathrm{CH}_{3}\right)_{3} \mathrm{GeCH}_{2} \mathrm{CHO}$, was found in the reaction mixture, but it did not seem that there is a fast equilibrium between the tautomers.

All these vinyloxygermanes were found polymerizable by radical and cationic initiators. The polymers were converted into poly(vinyl alcohol) by methanolysis in the presence of sodium methoxide or simply by the addition. of methanol into the polymerization mixture after polymerization.

The rate of radical homopolymerization was found to increase with increasing number of vinyloxy groups. The radical polymerization of di- and tri-vinyloxygermanes seemed to involve cyclopolymerization with the formation of a large amount of five-membered rings in addition to six-membered ones.
\end{abstract}

KEY WORDS Methylvinyloxygermanes / Vinyloxy compounds / Mercuridiacetaldehyde / Cyclopolymerization / Germanes / Tautomeric Isomerism / Radical Polymerization / Cationic Polymerization | Poly(vinyl alcohol) /

A number of vinyloxymetal compounds have been reported in literature, such as on aluminium,,${ }^{1}$ titanium, ${ }^{2}$ lithium, ${ }^{3}$ sodium,${ }^{3}$ iron, ${ }^{3}$ magnesium, ${ }^{3}$ silicon, ${ }^{4}$ and germanium. ${ }^{5}$ These vinyloxymetal compounds may be regarded as a new class of vinyl monomers, but there have been few studies concerning their polymerizability, their structure and the nature of the double bond.

In the case of vinyloxy compounds of the elements of the fourth group in the periodic table, there is a possibility of the keto form compounds as tautomeric isomers. In fact, both

$$
\begin{aligned}
& \mathrm{M}-\mathrm{O}-\mathrm{CH}=\mathrm{CH}_{2} \quad \mathrm{M}-\mathrm{CH}_{2} \mathrm{CHO} \\
& \text { Vinyloxy form }
\end{aligned}
$$

the vinyloxy compounds and the derivatives of keto form compounds of silicon are known as stable compounds. ${ }^{4,6-8}$ Furthermore, it is known that a keto form silicon compound is isomerized to a vinyloxysilane thermally ${ }^{9}$ or catalytically. ${ }^{10}$ Vinyloxytin compounds have not been synthesized but keto form compounds are known. ${ }^{11,12}$
As for germanium, only two have been reported as vinyloxy compounds, which were synthesized by Lutsenko, et al. ${ }^{5}$ It was

$$
\begin{aligned}
\mathrm{R}_{3} \mathrm{GeH} & +\mathrm{Hg}\left(\mathrm{CH}_{2} \mathrm{CHO}\right)_{2} \\
& \longrightarrow \mathrm{R}_{3} \mathrm{GeOCH}=\mathrm{CH}_{2}(\mathrm{R}=\mathrm{Pr} \text { and } \mathrm{Bu})
\end{aligned}
$$

recently reported that isopropenyloxytrimethylgermane is in a slow equilibrium with its tautomer at room temperature as shown below. ${ }^{13}$

$$
\begin{aligned}
& \left(\mathrm{CH}_{3}\right)_{3} \mathrm{GeOC}=\mathrm{CH}_{2} \rightleftarrows\left(\mathrm{CH}_{3}\right)_{3} \mathrm{GeCH}_{2} \mathrm{COCH}_{3} \\
& \stackrel{\mathrm{C}}{\mathrm{C}} \mathrm{H}_{3}
\end{aligned}
$$

The object of the present work is to attempt to synthesize a series of fundamental derivatives of vinyloxygermane and to study the polymerizability and other properties.

\section{EXPERIMENTAL}

Methylvinyloxygermanes were synthesized according to the following scheme. 


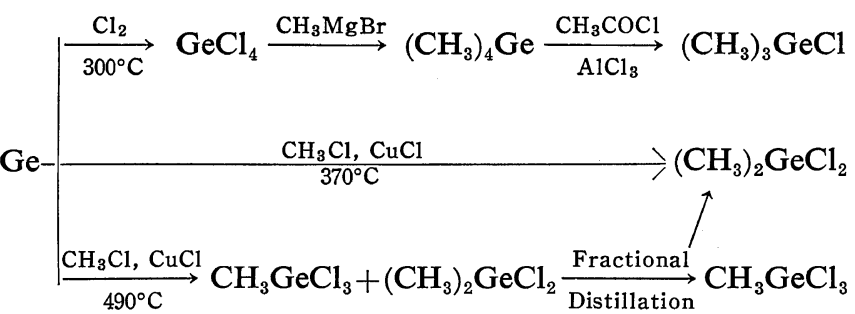

$$
\begin{aligned}
& \left(\mathrm{CH}_{3}\right)_{4-n} \mathrm{GeCl}_{n}+n \mathrm{Hg}\left(\mathrm{CH}_{2} \mathrm{CHO}\right)_{2} \longrightarrow\left(\mathrm{CH}_{3}\right)_{4-n} \mathrm{Ge}\left(\mathrm{OCH}=\mathrm{CH}_{2}\right)_{n}+n \mathrm{ClHgCH}_{2} \mathrm{CHO} \\
& (n=1 \sim 4)
\end{aligned}
$$

\section{Synthesis of Trimethylchlorogermane}

Tetramethylgermane was prepared by the reaction of germanium tetrachloride and methylmagnesium bromide in di- $n$-butyl ether, ${ }^{14}$ bp $44^{\circ} \mathrm{C}$, $83.5 \%$ yield. Trimethylchlorogermane was prepared by the action of acetyl chloride and anhydrous aluminum chloride on tetramethylgermane: ${ }^{15} \mathrm{mp}-13.5^{\circ} \mathrm{C}$ (lit. ${ }^{16}-14^{\circ} \mathrm{C}$ ); yield $91.5 \%$. Its purity was at least $98 \%$ by gas chromatography and it was used for the further reaction without purification.

\section{Synthesis of $\left(\mathrm{CH}_{3}\right)_{4-n} \mathrm{GeCl}_{n}(n=2 \sim 4)$}

These were prepared by the direct reaction of germanium metal and methyl chloride or chlorine. ${ }^{16,17}$ When germanium powder was heated at $370^{\circ} \mathrm{C}$ in the stream of methyl chloride using freshly prepared cuprous chloride ${ }^{18}$ as a catalyst, dimethyldichlorogermane was obtained in good yields. It was used for the next reaction after distillation. When the reaction was similarly carried out at $490^{\circ} \mathrm{C}$, methyltrichlorogermane was obtained as a major product accompanied by a minor amount of dimethyldichlorogermane. It was fractionated through a spinning band column, bp for methyltrichlorogermane $106-108^{\circ} \mathrm{C}$ and for dimethyldichlorogermane $119^{\circ} \mathrm{C}$. Since the germanium tetrachloride obtained by the reaction of germanium with chlorine at $300^{\circ} \mathrm{C}$ contained chlorine gas, it was distilled under nitrogen, bp $85-86^{\circ} \mathrm{C}$.

Synthesis of $\left(\mathrm{CH}_{3}\right)_{4-n} \mathrm{Ge}\left(\mathrm{OCH}=\mathrm{CH}_{2}\right)_{n} \quad(n=1 \sim 4)$

These were synthesized by the reaction of the corresponding methylchlorogermane and mercuridiacetaldehyde similar to the method of Nesmeyanov, et al.,$^{4}$ who used the reaction in the synthesis of vinyloxysilane compounds.

Trimethylvinyloxygermane $(n=1)$ was synthesized as follows. Prior to the reaction all glass vessels were flamed under reduced pressure and filled with nitrogen. A solution of $14.0 \mathrm{~g}(0.092$ mol) of trimethylchlorogermane in $15 \mathrm{ml}$ dry xylene was added dropwise at room temperature to a mixture of $40.0 \mathrm{~g}(0.14 \mathrm{~mol})$ of mercuridiacetaldehyde and $60-\mathrm{m} l$ xylene in a three-necked flask equipped with an air-tight stirrer, a reflux condenser, and a dropping funnel. After the addition, the reaction mixture was stirred for $3 \mathrm{hr}$ at room temperature and for $2 \mathrm{hr}$ at $60^{\circ} \mathrm{C}$. From this reaction mixture, volatile parts were collected in a Dry Ice-methanol trap by evaporation at room temperature under reduced pressure. After a simple distillation under reduced pressure, the distillate was subjected to rectification through a fractionating column packed with glass helices for 60-cm long; bp 47 $49.5^{\circ} \mathrm{C}(85 \mathrm{~mm})$; yield, $67.5 \%$.

Anal. Calcd for $\mathrm{C}_{5} \mathrm{H}_{12} \mathrm{GeO}$ : C, 37.36; $\mathrm{H}, 7.53$.

Found: C, 37.08; H, 7.42.

As it was difficult to remove completely the unreacted trimethylchlorogermane, this product was used for the polymerization without further purification. It contained about 1-\% trimethylchlorogermane.

Dimethyldivinyloxygermane $(n=2)$ was synthesized by the reaction of $15.0 \mathrm{~g}(0.09 \mathrm{~mol})$ of dimethyldichlorogermane and $69.0 \mathrm{~g}(0.24 \mathrm{~mol})$ of mercuridiacetaldehyde in ether. The reaction mixture was stirred under reflux for $2.5 \mathrm{hr}$. The monomer was twice distilled through a Vigreux column: bp $46.5^{\circ} \mathrm{C}(15 \mathrm{~mm}) ; \mathrm{mp}-15^{\circ} \mathrm{C}$; yield, 62\%.

Anal. Calcd for $\mathrm{C}_{6} \mathrm{H}_{12} \mathrm{GeO}_{2}$ : C, 38.18; $\mathrm{H}, 6.41$. Found: C, 37.86; H, 6.35.

Methyltrivinyloxygermane $(n=3)$ was synthesized by the reaction of $12.0 \mathrm{~g}(0.062 \mathrm{~mol})$ of methyltrichlorogermane and $100 \mathrm{~g}(0.35 \mathrm{~mol})$ of 
mercuridiacetaldehyde in ether. The reaction mixture was filtered under nitrogen atmosphere and the filtrate, after the evaporation of ether in vacuo, was distilled under reduced pressure: bp $37^{\circ} \mathrm{C}(2.5 \mathrm{~mm})$; yield, $57 \%$.

Anal. Calcd for $\mathrm{C}_{7} \mathrm{H}_{12} \mathrm{GeO}_{3}: \mathrm{C}, 38.78 \mathrm{H}, 5.58$. Found: $\mathrm{C}, 38.63 \mathrm{H}, 5.72$.

In an attempt to synthesize tetravinyloxygermane $(n=4)$, a solution of $9.4 \mathrm{~g}(0.044 \mathrm{~mol})$ of germanium tetrachloride in $30 \mathrm{~m} l$ of $n$-hexane was added dropwise into a mixture of $55.0 \mathrm{~g}$ $(0.19 \mathrm{~mol})$ of mercuridiacetaldehyde and $100 \mathrm{~m} l$ of $n$-hexane under stirring at room temperature. The temperature elevation of the reaction mixture was observed upon addition of the germanium tetrachloride solution and the appearance of gray mercuridiacetaldehyde crystal was clearly changed into a white powder. The IR spectrum of the powder was similar to that of chloromercuriacetaldehyde. The IR spectrum of the supernatent liquid showed absorption bands at $1640,1145,990$, and $965 \mathrm{~cm}^{-1}$ which are characteristic of the vinyloxy group. From these facts, it is sure that the vinyloxy compound was formed but its high polymerizability made the isolation difficult.

Physical constants of methylvinyloxygermanes are summarized in Table I.

Measurement of the Rate of Radical Polymerization

These compounds were polymerized in benzene in the presence of azobisisobutyronitrile (AIBN) using a dilatometer at a vinyloxy concentration of $2.0 \mathrm{~mol} / l$. The dilatometric technique was used to confirm the absence of the induction period. After the polymerization, the content of the dilatometer was transfered to a flask, and the solvent and unpolymerized monomer were removed by the fleeze-drying technique under high vacuum. Conversion was calculated from the amount of the residual polymer, taking account of the initiator.

\section{Cationic Polymerization}

Monomer and solvent were cooled to a Dry Ice-methanol temperature in a Schlenk tube under nitrogen and a cationic initiator was added as a $n$-hexane solution of $1 \mathrm{~mol} / l$.

\section{Derivation into Poly(vinyl alcohol) $(P V A)$}

A polymer of vinyloxygermanes was dissolved in methanol and stood overnight at room temperature after the addition of a few drops of a dilute sodium methoxide solution in methanol. Methanol was evaporated in vacuo and the residue was dissolved in water and dialyzed for two days. Insoluble substances were removed with a glass filter and the filtrate was dried by freeze-drying. PVA was also obtained by the addition of a large amount of methanol into the polymerization mixture followed by evaporation, dialysis in water, and freeze-drying. The latter procedure was used in cases where the isolation of poly(vinyloxygermane) was not required.

Table I. Physical constants of methylvinyloxygermanes $\left(\mathrm{CH}_{3}\right)_{4-n} \mathrm{Ge}\left(\mathrm{OCH}=\mathrm{CH}_{2}\right)_{n}$

\begin{tabular}{ccccc}
\hline$n$ & & 1 & 2 & 3 \\
\hline$n_{\mathrm{D}}\left({ }^{\circ} \mathrm{C}\right)$ & & $1.4345(16)$ & $1.4526(19)$ & $1.4550(19)$ \\
\hline & $\nu_{\mathrm{C}=\mathrm{C}}$ & 1623 & 1628 & 1632 \\
& $\nu_{\mathrm{C}-\mathrm{O}}$ & 1176 & 1165 & 1155 \\
& $\delta_{=\mathrm{C}-\mathrm{H}}$ & 990 & 990 & 990 \\
& $\nu_{\mathrm{Ge}-\mathrm{O}}$ & & & 965 \\
& or & 973 & 970 & \\
& $\delta_{=\mathrm{C}-\mathrm{H}}$ & & & 1.4 \\
& $\lambda_{\mathrm{max}}$ & 195 & 0.95 & 6.55 \\
& $J_{\mathrm{gem}(\mathrm{Hz})}$ & 0.6 & 6.41 & $4.17,4.47$ \\
& $\delta_{=\mathrm{CH}(\mathrm{ppm})}$ & 6.37 & $3.98,4.23$ & 0.97 \\
\hline
\end{tabular}

a Determined in gas phase.

b $\delta$-Values were determined in $\mathrm{CCl}_{4}$ solutions using TMS as an internal standard. 


\section{Measurement of the Content of Pendant Vinyl Group}

Polymer was dipped in an excess of $1 / 2-N$ hydroxylamine sulfate aqueous solution. Acetaldehyde which was formed by hydrolysis of the remaining vinyloxy group was allowed to react with hydroxylamine sulfate. Liberated sulfuric acid was titrated by $1 / 10-N$ sodium hydroxide solution using bromophenol blue as an indicator.

\section{Determination of 1,2-Glycol Content in PVA}

1,2-Glycol content was determined by titrating the periodic acid comsumption by PVA in accordance with the method used by Harris and Prichard. ${ }^{19}$

\section{Degree of Polymerization of PVA}

It was calculated from a specific viscosity of a 1-\% aqueous PVA solution according to the equation presented by Nakajima. ${ }^{20}$

\section{IR Spectra}

IR spectra were measured by liquid film for liquid sample and by $\mathrm{KBr}$ tablet for PVA.

\section{RESULTS AND DISCUSSION}

\section{Preparation of Monomer}

Methylvinyloxygermanes were synthesized by the reaction of the corresponding methylchlorogermanes and mercuridiacetaldehyde in inert solvents under nitrogen atmosphere. All these compounds are very sensitive to water and are hydrolyzed even by atmospheric moisture.

Figure 1 shows the IR spectra of methylvinyloxygermanes in a region of 1400 to $3600 \mathrm{~cm}^{-1}$. Each spectrum shows a weak absorption at 1735 $\mathrm{cm}^{-1}$ assigned to $\nu_{\mathrm{C}=\mathrm{O}}$ of acetaldehyde, which is formed by hydrolysis of the $\mathrm{Ge}-\mathrm{O}$ bond by moisture. In the spectrum of monovinyloxygermane, there is another strong $\nu_{\mathrm{C}=0}$ absorption at $1705 \mathrm{~cm}^{-1}$ and also weak absorptions at 2710 and $2800 \mathrm{~cm}^{-1}$ which may be assigned to $\nu_{\mathrm{C}-\mathrm{H}}$ of aldehyde group. These latter two may not be absorptions of acetaldehyde judging from their intensity, but may be associated with the aldehyde group which shows the absorption at $1705 \mathrm{~cm}^{-1}$. In both the spectra of di- and trivinyloxygermanes, there is no absorption of the aldehyde group.

NMR spectra of monovinyloxygermane are

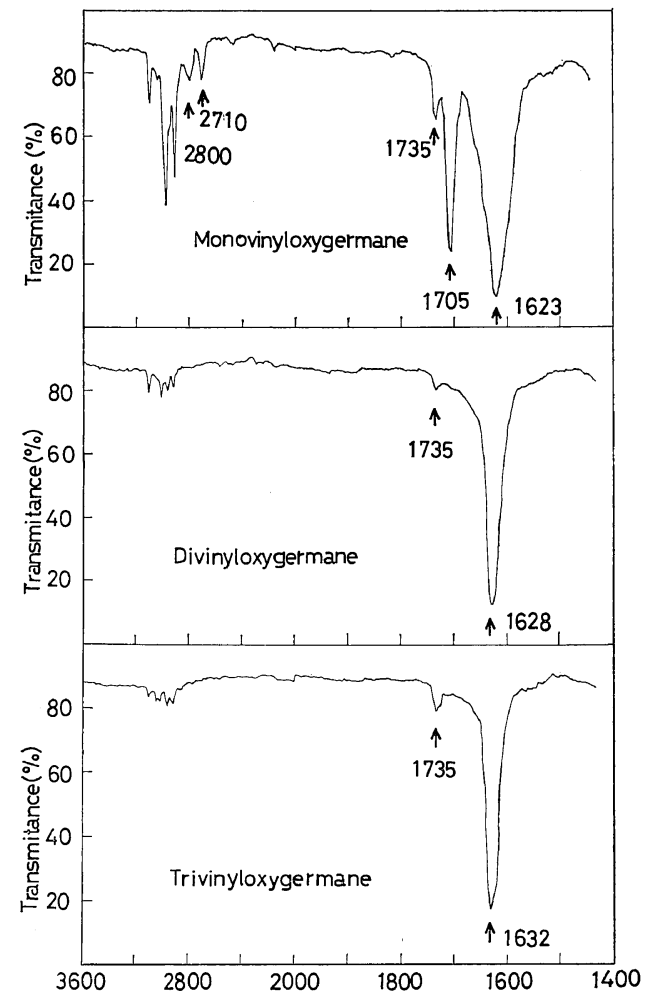

Figure 1. IR spectra of methylvinyloxygermans.

shown in Figure 2. In addition to methyl and vinyl protons, there is a doublet at $\delta 2.02$ and a triplet at $\delta 9.47$. These may be reasonably assigned to methylene and aldehyde protons of the $-\mathrm{CH}_{2} \mathrm{CHO}$, respectively. Moreover, there exist two kinds of mythyl protons at $\delta 0.08$ and $\delta 0.26$. (Signal at $\delta 0.48$ is considered as methyl protons of trimethylchlorogermane. Lit. ${ }^{21} \delta 0.49$.) There were neither of these abnormal signals in the spectra of di- and tri-vinyloxygermanes.

It may be concluded from these facts that the vinyloxy compound is the main product in the reaction of trimethylchlorogermane and mercuridiacetaldehyde but its tautomeric isomer, keto compound, is also prepared as a by-product in about $10 \%$.

$$
\begin{aligned}
& \left(\mathrm{CH}_{3}\right)_{3} \mathrm{GeCl}+\mathrm{Hg}\left(\mathrm{CH}_{2} \mathrm{CHO}\right)_{2} \\
& \longrightarrow\left(\mathrm{CH}_{3}\right)_{3} \mathrm{GeOCH}=\mathrm{CH}_{2}+\left(\mathrm{CH}_{3}\right)_{3} \mathrm{GeCH}_{2} \mathrm{CHO} \\
& 90 \% \\
& 10 \%
\end{aligned}
$$

Data of IR and NMR of both tautomers are summerized in Table II, although the keto compound has not been isolated. 


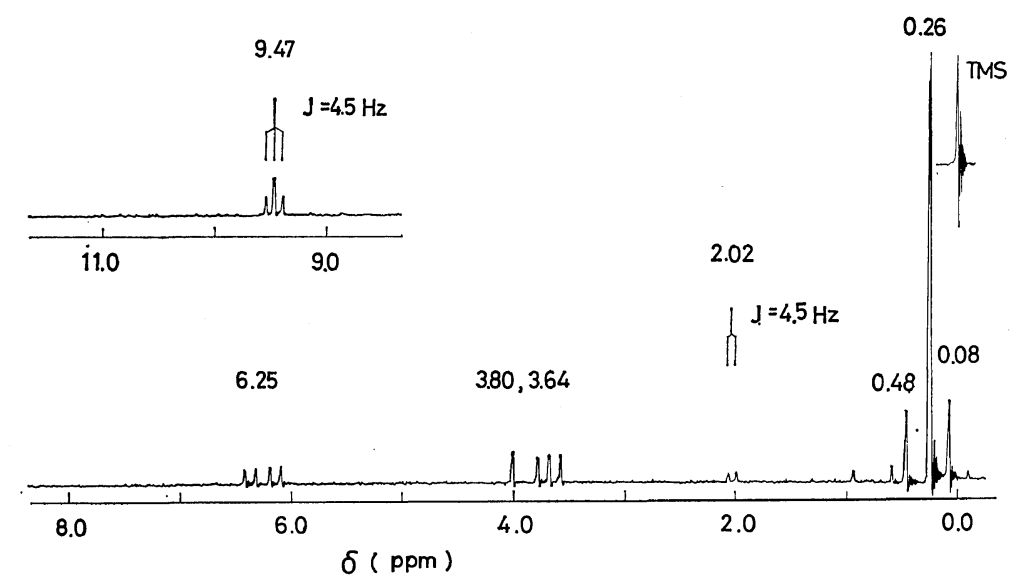

Figure 2. NMR spectrum of monovinyloxygermane.

Table II. IR and NMR data of trimethylvinyloxygermane and its tautomer

\begin{tabular}{|c|c|c|c|c|}
\hline & \multicolumn{2}{|c|}{ Vinyloxy form } & \multicolumn{2}{|c|}{ Keto form } \\
\hline \multirow{6}{*}{ IR data, $\mathrm{cm}^{-1}$} & $\nu_{\mathrm{C}}=\mathrm{C}$ & 1623 & $\nu_{\mathrm{C}-\mathrm{H}}$ & 2800,2710 \\
\hline & $\nu_{\mathrm{C}-\mathrm{O}}$ & 1176 & $\nu_{\mathrm{C}}=0$ & 1705 \\
\hline & $\delta=\mathrm{C}-\mathrm{H}$ & 990 & & \\
\hline & $\nu_{\mathrm{Ge}-\mathrm{O}}$ & & & \\
\hline & or & 973 & & \\
\hline & $\delta=\mathrm{C}-\mathrm{H}$ & & & \\
\hline \multirow{3}{*}{ NMR data, ${ }^{a}$ ppm } & $\delta \mathrm{CH}_{3}$ & 0.26 & $\delta \mathrm{CH}_{3}$ & 0.08 \\
\hline & $\delta=\mathrm{CH}_{2}$ & $3.64,3.80$ & $\delta_{\mathrm{CH}_{2}}$ & 2.02 \\
\hline & $\delta=\mathrm{CH}$ & 6.25 & $\delta \mathrm{CHO}$ & 9.47 \\
\hline
\end{tabular}

a $\delta$-Values were determined in $\mathrm{CCl}_{4}$ solution using TMS as an internal standard.

Lutsenko, et al., have reported that an enolate and a keto form compound are prepared by the following reaction and a slow equiliblium exists at room temperature between the tautomers. ${ }^{13}$

$$
\begin{gathered}
\left(\mathrm{CH}_{3}\right)_{3} \mathrm{GeBr}+\mathrm{Pr}_{3} \mathrm{SnCH}_{2} \mathrm{COCH}_{3} \\
\longrightarrow\left(\mathrm{CH}_{3}\right)_{3} \mathrm{GeOC}=\mathrm{CH}_{2}+\left(\mathrm{CH}_{3}\right)_{3} \mathrm{GeCH}_{2} \mathrm{COCH}_{3} \\
\stackrel{\mathrm{C}}{\mathrm{CH}} \mathrm{H}_{3}
\end{gathered}
$$

Investigations were carried out to see whether an equilibrium exists between trimethylvinyloxygermane and trimethylgermylacetaldehyde. The relative intensities of the characteristics signals of both the tautomers were neither appreciably changed by standing at Dry Ice temperature for a few weeks nor by changing the temperature of NMR measurement from -46.5 to $82^{\circ} \mathrm{C}$. A sample of trimethylvinyloxygermane having no characteristic band of the keto com- pound in IR and NMR spectra was obtained by a careful fractional distillation. It is certain therefore that there is at least no fast equilibrium between the tautomers.

In the reaction of mercuridiacetaldehyde or chloromercuriacetaldehyde, O-vinylation takes place in many cases ${ }^{1,3-5}$ and $\mathrm{C}$-alkylation has been reported in some cases. ${ }^{22}$ The above fact indicates that this may be a rare case where both the O-vinylation and the C-alkylation took place at the same time.

\section{Polymerization}

Vinyl ether, a monovinyloxycarbon compound, is not polymerized by a radical initiator, but both divinyl acetal and divinyl ketal, divinyloxycarbon compounds, are polymerizable..$^{11,23}$ Vinyloxysilicon homologs hold a similar situation. The rate of polymerization of methyl- 
vinyloxygermanes was measured for the sake of comparison using AIBN as a initiator. Results are shown in Table III.

Table III. Rate of radical polymerization of $\left(\mathrm{CH}_{3}\right)_{4-n} \mathrm{Ge}\left(\mathrm{OCH}=\mathrm{CH}_{2}\right)_{n}$ in benzene at $60^{\circ} \mathrm{Ca}^{\mathrm{a}}$

\begin{tabular}{cccc}
\hline$n$ & Time, hr & Conversion, \% & Rate, $\% / \mathrm{hr}$ \\
\hline 1 & 14.25 & 1.7 & 0.12 \\
2 & 6.38 & 8.9 & 1.4 \\
3 & 1.03 & 16.9 & 16.4 \\
\hline
\end{tabular}

a $[\mathrm{M}]=2.0 \mathrm{~mol} / \mathrm{l}$ as vinyl concentration, $[\mathrm{AIBN}]=$ $1.1 \times 10^{-2} \mathrm{~mol} / l$.

There was no induction period in the radical polymerization of methylvinyloxygermanes. The rate increases with an increasing number of vinyloxy groups. The amount of pendant vinyl in polymer was measured by the hydroxylamine method. Results are shown in Table IV.

In all cases, the content of the pendant vinyl group is about $20 \%$. It indicates that cyclopolymerization has taken place to some extent, because if the cyclopolymerization did not occur, the content of the pendant vinyl would be $50 \%$ for poly(divinyloxygermane) and $66.7 \%$ for poly (trivinyloxygermane). This is also confirmed by the structure of PVA derived from poly(methylvinyloxygermane).

All methylvinyloxygermanes were polymerized by typical cationic initiators. Results are shown in Table V.

On addition of catalysts, the polymerization system became milky in the case of monovinyloxygermane and white solids were precipitated immediately in the cases of di- and tri-vinyloxygermanes.

\section{The Structure of Derived PVA}

PVA was obtained by methanolysis in the presence of sodium methoxide or simply by the addition of a large amount of methanol into the polymerization mixture after polymerization.

The IR spectra of these PVA are shown in Figure 3, together with a commercial PVA and a PVA having 15-\%, 1,2-glycol structure. ${ }^{24}$ The IR spectra of PVA derived from radical polymers differ from those from cationic polymers in that the latter has a absorption band at $1090 \mathrm{~cm}^{-1}$ but the band shifted to $1055 \mathrm{~cm}^{-1}$ in the former. Optical density ratio $D_{916} / D_{849}$ of the radical poly-

Table IV. Pendant vinyl and 1,2-glycol concentrations in polymer of methylvinyloxygermanes $\left(\mathrm{CH}_{3}\right)_{4-n} \mathrm{Ge}\left(\mathrm{OCH}=\mathrm{CH}_{2}\right)_{n}$

\begin{tabular}{clccc}
\hline$n$ & $\begin{array}{c}\text { Polymerization } \\
\text { condition }\end{array}$ & $\begin{array}{c}\text { Pendant vinyl concn, } \\
\%\end{array}$ & $\begin{array}{c}\text { 1,2-Glycol concn in } \\
\text { derived PVA, } \%\end{array}$ & $\overline{D P}$ \\
\hline 2 & AIBN, bulk & 24 & 23 & 130 \\
2 & AIBN, $0.6 \mathrm{~mol} / l^{\mathrm{a}}$ & 24 & & \\
3 & $\mathrm{AIBN}, 2 \mathrm{~mol} / \mathrm{l}^{\mathrm{a}}$ & 14 & 25 & 90 \\
3 & $\mathrm{SnCl}_{4}{ }^{\mathrm{b}}$ & 13 & 3 & \\
\hline
\end{tabular}

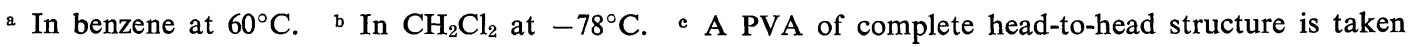
to be $50 \%$.

Table V, Cationic polymerization of $\left(\mathrm{CH}_{3}\right)_{4-n} \mathrm{Ge}\left(\mathrm{OCH}=\mathrm{CH}_{2}\right)_{n}{ }^{\mathrm{a}}$

\begin{tabular}{llcccc}
\hline$n$ & Solvent & $\begin{array}{c}\mathrm{M}, \\
\text { Vol } \%\end{array}$ & $\begin{array}{c}\text { Initiator, } \\
\text { m mol }\end{array}$ & $\begin{array}{c}\text { Time, } \\
\text { hr }\end{array}$ & $\begin{array}{c}\text { Yield, } \\
\%\end{array}$ \\
\hline 1 & $\mathrm{CH}_{2} \mathrm{Cl}$ & 5 & $\mathrm{SnCl}_{4}(1.5)$ & 72 & 36 \\
1 & Toluene & 5 & $\mathrm{EtAlCl}_{2}(0.9)$ & 72 & 37 \\
1 & Toluene & 10 & $\mathrm{EtAlCl}_{2}(0.6)$ & 5 & 56 \\
2 & $\mathrm{CH}_{2} \mathrm{Cl}_{2}$ & 5 & $\mathrm{SnCl}_{4}(0.3)$ & 20 & 86 \\
2 & $\mathrm{EtNO}_{2}$ & 5 & $\mathrm{SnCl}_{4}(0.3)$ & 6 & 91 \\
3 & $\mathrm{CH}_{2} \mathrm{Cl}_{2}$ & 5 & $\mathrm{SnCl}_{4}(0.3)$ & 6 & 43 \\
\hline
\end{tabular}

a Polymerization temp, $-78^{\circ} \mathrm{C}$. 


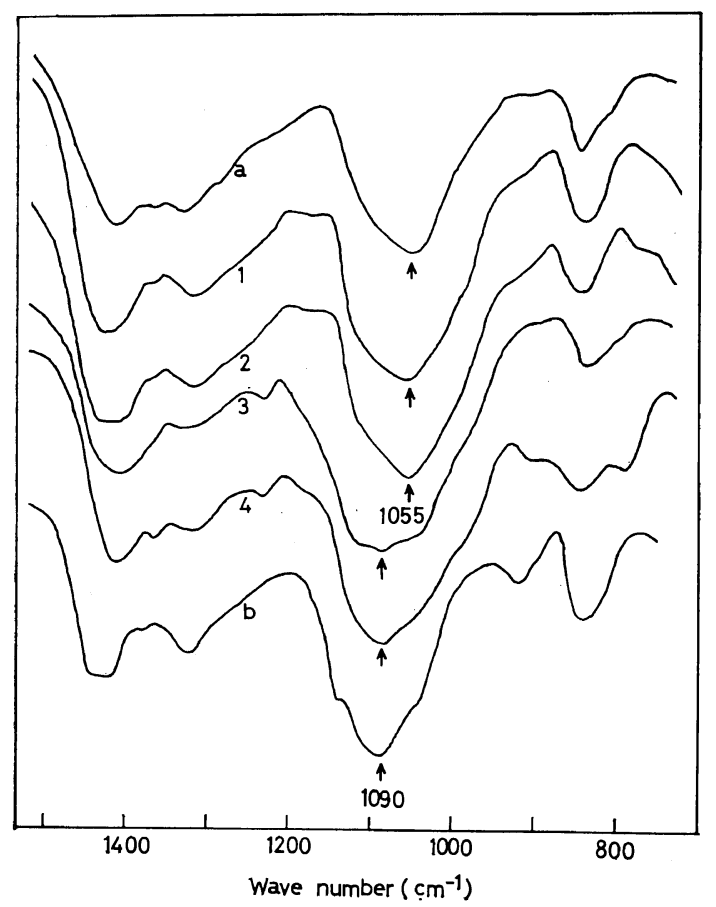

Figure 3. IR spectra of PVA derived from poly (methylvinyloxygermane):

a, PVA containing 15\% 1,2-glycol structure ${ }^{23}$;

b, Commercial PVA;

1, PVA from poly(divinyloxygermane), AIBN, bulk, at $60^{\circ} \mathrm{C}$;

2, PVA from poly(trivinyloxygermane), AIBN, in benzene, at $60^{\circ} \mathrm{C}$;

3, PVA from poly(divinyloxygermane), $\mathrm{SnCl}_{4}$, in $\mathrm{CH}_{2} \mathrm{Cl}_{2}$, at $-78^{\circ} \mathrm{C}$;

4, PVA from poly(trivinyloxygermane), $\mathrm{SnCl}_{4}$ in $\mathrm{CH}_{2} \mathrm{Cl}_{2}$, at $-78^{\circ} \mathrm{C}$.

mer is very small and the band at $849 \mathrm{~cm}^{-1}$ is broad. From previous studies, ${ }^{24}$ it is deduced that these characteristics are caused by a large amount of the 1,2-glycol structure. Actually, the 1,2-glycol content determined by the periodic acid consumption is about $25 \%$.

It is considered that the formation of the fivemembered ring probably takes place in the radical polymerization to a considerable degree, yielding the 1,2-glycol unit on solvolysis.

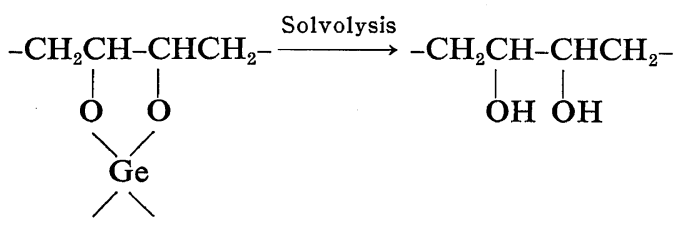

Since the IR spectra of PVA derived from the cationic polymer showed the absorption at 1090 $\mathrm{cm}^{-1}$, the polymers may have cyclyzed mainly to the six-membered ring.

Acknowlegement. The authors express thanks to Prof. M. Kumada, Kyoto University, for his guidance in the preparation of methylchlorogermanes.

\section{REFERENCES}

1. L. I. Zakharkin, Izv. Akad. Nauk SSSR, Otdel. Khim. Nauk, 1962, 378.

2. J. H. Haslam, U.S. Patent 2708205 (1955).

3. A. N. Nesmeyanov, and I. F. Lutsenko, Dokl. Akad. Nauk SSSR, 120, 1049 (1958).

4. A. N. Nesmeyanov and I. F. Lutsenko, Dokl. Akad. Nauk SSSR, 128, 551 (1959).

5. Yu. I. Baukov and I. F. Lutsenko, Zh. Obschei Khim., 32, 3838 (1962).

6. H. R. Hauser and C. R. Hance, J. Amer. Chem. Soc., 71, 5091 (1952).

7. A. G. Brook, W. W. Limbury, D. M. MacRae, and S. A. Fieldhaus, J. Amer. Chem. Soc. 89, 704 (1967).

8. Yu. I. Baukov, G. S. Burlachenko, I. Yu. Belavin, and I. F. Lutsenko, Zh. Obschei Khim. 36, 153 (1966).

9. A. G. Brook, D. M. MacRae, and W. W. Limburg, J. Amer. Chem. Soc., 89, 5493 (1967).

10. O. V. Litwinova, Yu. I. Baukov, and I. F. Lutsenko, Dokl. Akad. Nauk SSSR, 173578 (1968), I. F. Lutsenko, Yu. I. Baukov, O. V. Dudukina, and E. N. Kramarava, J. organometal. Chem., 11, 35 (1968).

11. M. Furue, unpublished experimental.

12. A. N. Nesmeyanov, I. F. Lutsenko, and S. V. Doramarev, Dokl. Akad. Nauk SSSR, 124, 1073 (1959).

13. I. F. Lutsenko, Yu. I. Baukov, I. Yu. Belavin, and A. N. Trarogov, J. Organometal. Chem., 14, 229 (1968).

14. D. F. Van de Vonde1, J. Organometal. Chem., 3, 400 (1966).

15. H. Sakurai, K. Tominaga, T. Watanabe, and M. Kumada, Tetrahedron Lett., 45, 5493 (1966); private communication from M. Kumada, et al.

16. M. Schmidt and I. Ruidish, Zeit. anorg. und all. Chem., 311, 331 (1961).

17. Private communication from M. Kumada, et al.

18. W. C. Fenelius, "Inorganic Synthesis," Vol. II, McGraw-Hill New York, N.Y., 1946, p 1.

19. H. E. Harris and J. G. Prichard, J. Polym. Sci., 
Part A, 2, 3673 (1964).

20. A. Nakajima and K. Furutake, Kobunshi Kagaku (Chem. High Polymers), 6, 460 (1949).

21. A. N. Egorochkin, M. L. Khidehel, and V. A. Ponomarenko, Izv. Akad. Nauk SSSR, Otdel. Khim. Nauk, 1964, 373.

22. A. N. Nesmeyanov, I. F. Lutsenko, and Z. M. Tumanova, Izv. Akad. Nauk SSSR, Otdel. Khim. Nauk, 1949, 1601; D. N. Kursanov, M. E.
Volpin, and I. S. Okhrem, Dokl. Akad. Nauk $S S S R, 120,531$ (1958).

23. S. G. Matsoyan, J. Polym. Sci., 52, 189 (1961); S. G. Matsoyan and A. A. Soakyan, Polymer Sci., USSR, 3, 921 (1962).

24. K. Kikukawa, S. Nozakura, and S. Murahashi, Kobunshi Kagaku (Chem. High Polymers), 25, 19 (1968). 